\title{
Removal of Cd(II) from Aqueous Solutions by Aluminium Hydroxide-Modified Attapulgite
}

\author{
Qinhu Zhang, Liqun Cai* \\ College of Resources and Environment, Gansu Agricultural University, Lanzhou, China
}

Received: 27 July 2020

Accepted: 2 November 2020

\begin{abstract}
Modified attapulgite (ATP-Al) was prepared with aluminium hydroxide through a co-precipitation method, and we used ATP-Al as an adsorbent to investigate the adsorption of $\mathrm{Cd}$ (II) from aqueous solutions. Raw ATP and ATP-Al were characterized by TEM, FTIR, XRD and Zeta. Adsorption parameters, such as $\mathrm{pH}$, initial $\mathrm{Cd}(\mathrm{II})$ concentration, contact time and adsorbent dose, were evaluated to explain the mechanism of $\mathrm{Cd}(\mathrm{II})$ adsorption on ATP-Al. ATP-Al had a better adsorption capacity of Cd(II) than ATP. When the $\mathrm{pH}$ value was 7, ATP and ATP-Al had the highest Cd(II) adsorption capacities. The optimal dose of adsorbent was $0.1 \mathrm{~g}$ per $25 \mathrm{~mL}$ of solution. The Freundlich model better described the adsorption isotherm on ATP and ATP-Al than the Langmuir model. The maximum adsorption capacity for $\mathrm{Cd}(\mathrm{II})$ calculated was 4.01 and $6.36 \mathrm{mg} \mathrm{g}^{-1}$, respectively. Adsorption of $\mathrm{Cd}(\mathrm{II})$ onto ATP and ATP-Al followed pseudo-second order kinetics. The Gibbs free energy $\left(\Delta \mathrm{G}^{\circ}\right)$, enthalpy $\left(\Delta \mathrm{H}^{\circ}\right)$ and entropy $\left(\Delta \mathrm{S}^{\circ}\right)$ were evaluated by a thermodynamic study. The adsorption processes of ATP and ATP-Al were exothermic, spontaneous and mainly based on physical adsorption.
\end{abstract}

Keywords: attapulgite, aluminium hydroxide, Cd(II), adsorption

\section{Introduction}

Cadmium is not an essential element but is one of the most hazardous trace elements. It is released into the environment from metallurgical plants, lead-zinc mines, pigments and chemical industries. From the perspective of potential harm to human health, cadmium is regarded as a "priority metal" [1]. A small amount of Cd(II) seriously damages the human lungs, liver and kidneys [2]. The maximum concentration of $\mathrm{Cd}$ (II) in drinking water is $0.003 \mathrm{mg} \mathrm{L}^{-1}$; this level was set by the World Health Organization (WHO). At present, Cd(II)

*e-mail: cailq@gsau.edu.cn has widely polluted drinking water; therefore, we must remove it or reduce the concentration of $\mathrm{Cd}(\mathrm{II})$ in wastewater as soon as possible.

Several methods for heavy metal removal from wastewater have been studied for many years. These methods include coagulation [3], precipitation [4], adsorption [5], ion-exchange and membrane technologies [6]. However, most of these methods have a high cost and complicated treatment process. Hence, their practical application is limited.

Adsorption is considered an effective method to remove heavy metals because of its inexpensive, high efficiency and easy operation. Several kinds of adsorbents, such as clays (zeolites [5], kaolinite [7], attapulgite [8]), metal oxides [9], and biochar [10], have been reported. Among these adsorbents, some 
researchers believe that clay minerals have great potential as inexpensive and efficient adsorbents because of their abundant reserves in nature and their high surface area and chemical and mechanical stability [11].

Attapulgite (ATP) is a hydrated magnesium silicate clay mineral that widely exists in nature. Due to its fibrous morphology, certain cation exchange capacity, and large specific surface area, it is favourable for heavy metal adsorption from aqueous solutions [12]. However, natural ATP has a relatively low $\mathrm{Cd}(\mathrm{II})$ adsorption capacity from aqueous solutions [13]. Therefore, we should modify or activate ATP to enhance its Cd(II) adsorption performance, and methods for improvement include acid treatment [13], alkali treatment [14], heat treatment [13], organic treatment [15], and inorganic composite treatment [16].

In inorganic composite treatment, several researchers coated ATP with aluminium hydroxides/oxide to synthesize a composite attapulgite ATP to remove heavy metals (arsenate [17]) and other contaminants (phosphate [18] and ethylene terephthalate [19]). Because aluminium hydroxide has a large amorphous structure and specific surface area, it can provide more adsorption sites on natural ATP [20, 21].

However, more adsorption sites on the surface of the attapulgite may improve the adsorption capacity for $\mathrm{Cd}(\mathrm{II})$. However, little information concerning the removal of $\mathrm{Cd}(\mathrm{II})$ with aluminium hydroxide-modified ATP (ATP-Al) has been reported. The adsorption characteristics and thermodynamics of Cd(II) by ATPAl have not been studied in detail to our knowledge. Therefore, it is necessary for us to study the adsorption of $\mathrm{Cd}$ (II) onto ATP-Al.

The main objectives of this work were as follows:

(1) synthesize aluminium hydroxide-modified attapulgite (ATP-Al);

(2) conduct batch experiments to determine the effect of $\mathrm{pH}$, initial $\mathrm{Cd}(\mathrm{II})$ concentration, contact time and adsorbent dose on the adsorption performance of $\mathrm{Cd}$ (II) onto ATP and ATP-Al through adsorption isotherm, adsorption kinetic studies and thermodynamics studies;

(3) TEM, FTIR, XRD and Zeta characterization methods were used to analyse the difference between ATP and ATP-Al;

(4) explain the interaction between ATP-Al and $\mathrm{Cd}(\mathrm{II})$ in aqueous solutions by analysing the difference in $\mathrm{Cd}(\mathrm{II})$ removal with ATP and ATP-Al.

\section{Experimental}

\section{Materials}

Natural ATP was acquired in Linze City of Gansu Province, China. Dissolving $2.75 \mathrm{~g}$ of cadmium nitrate $\left[\mathrm{Cd}\left(\mathrm{NO}_{3}\right)_{2} \cdot 4 \mathrm{H}_{2} \mathrm{O}\right]$ in $1 \mathrm{~L}$ of deionized water to prepare a stock cadmium solution $\left(1 \mathrm{~g} \mathrm{~L}^{-1}\right)$. Aluminium chloride $\left[\mathrm{AlCl}_{3} \cdot 6 \mathrm{H}_{2} \mathrm{O}, \mathrm{AR}\right.$ grade] was used to prepare the modified ATP. Other reagents were all of analytical grade. Deionized water was used to prepare all solutions.

\section{Characterization}

Fourier transform infrared (FTIR) spectra of adsorbents were recorded by an FT-IR spectrometer (Nicolet IS50, Thermo, Germany). The X-ray diffraction (XRD) of adsorbents was measured by a diffractometer (XD3, Puxi Co., China). TEM images were taken using a transmission electron microscope (JEM-1230, JEOL, Japan). Zeta potential was measured by a Nanobrook omni Particles/Protein Size and Zeta Potentials Analyzer (NanoBrook Omni, Brookhaven, USA). Cd(II) was determined by inductively coupled plasma optical emission spectrometry (ICP-OES) (ICP5000, Juguang Co., China).

\section{Preparation of ATP-Al}

ATP-Al synthesis was performed according to the following procedure:

Natural ATP (10 g) that was milled to a 200 mesh particle size was mixed with $400 \mathrm{~mL}$ of an aqueous solution containing $7.16 \mathrm{~g}$ of $\mathrm{AlCl}_{3} \cdot 6 \mathrm{H}_{2} \mathrm{O}(0.8 \mathrm{~g} \mathrm{Al})$ (the mass ratio of attapulgite to $\mathrm{Al}$ is 12.5:1). The mixture was stirred by a magnetic stirrer at $293 \mathrm{~K}$ and $160 \mathrm{rpm}$ while adding $\mathrm{NaOH}\left(1 \mathrm{~mol} \mathrm{~L}^{-1}\right)$ dropwise into the solution until the solution $\mathrm{pH}$ was stable at 7 . After the reaction, the formed suspension was continuously stirred for $12 \mathrm{~h}$. Then, the suspension was filtered, and deionized water was washed many times until there was no $\mathrm{Cl}^{-}$in the filtrate. After filtration, the solids were dried for $24 \mathrm{~h}$ at $383 \mathrm{~K}$ and then milled to a particle size of 200 mesh. The resulting powder was ATP-Al.

\section{Batch Adsorption Experiments}

All batch adsorption samples were shaken at 160 rpm by a thermostatic shaker bath, and the temperature was $303 \mathrm{~K}$. The $\mathrm{pH}$ values were adjusted with $0.1 \mathrm{~mol} / \mathrm{L}$ $\mathrm{HNO}_{3}$ or $0.1 \mathrm{~mol} / \mathrm{L} \mathrm{NaOH}$. When the reaction reached equilibrium, the suspensions were filtered with $0.45 \mu \mathrm{m}$ membranes. The $\mathrm{Cd}$ (II) concentration in the filtrate was determined by ICP-OES.

The adsorption capacity of Cd(II) was calculated by Eq. (1):

$$
\mathrm{Q}_{\mathrm{e}}=\frac{\left(\mathrm{C}_{0}-\mathrm{C}_{\mathrm{e}}\right) \mathrm{V}}{\mathrm{m}}
$$

...where $\mathrm{Q}_{\mathrm{e}}$ is the adsorption capacity of $\mathrm{Cd}(\mathrm{II})$, (mg $\left.\mathrm{g}^{-1}\right) ; \mathrm{C}_{\mathrm{e}}$ and $\mathrm{C}_{0}$ are the equilibrium concentration and the initial concentration of $\mathrm{Cd}(\mathrm{II}),\left(\mathrm{mg} \mathrm{L}^{-1}\right)$, respectively; $\mathrm{V}$ is the volume, $(\mathrm{L})$; and $\mathrm{m}$ is the dose of adsorbent, $(\mathrm{g})$.

Effect of pH: ATP and ATP-Al $(0.1 \mathrm{~g})$ were added to $25 \mathrm{~mL}$ of a $\mathrm{Cd}(\mathrm{II})$ solution in $50 \mathrm{~mL}$ centrifuge tubes. The initial concentration of $\mathrm{Cd}(\mathrm{II})$ was $10 \mathrm{mg} \mathrm{L}^{-1}$, and 
the $\mathrm{pH}$ was adjusted to $3,4,5,6$ and 7 with $\mathrm{HNO}_{3}$ or $\mathrm{NaOH}$.

Adsorption isotherms: ATP and ATP-Al (0.1 g) were added to $25 \mathrm{~mL}$ of $\mathrm{Cd}$ (II) solution at different initial concentrations (i.e., 1, 5, 10, 20, 50, 100, $200 \mathrm{mg} \mathrm{L}^{-1}$ ) in $50 \mathrm{~mL}$ centrifuge tubes. The $\mathrm{pH}$ values were adjusted to 6 . The above procedure was then repeated at $293 \mathrm{~K}$ and $313 \mathrm{~K}$ to calculate thermodynamic parameters.

Kinetic studies: One gram of ATP and ATPAl was added to $250 \mathrm{~mL}$ of a $\mathrm{Cd}(\mathrm{II})$ solution in a $250 \mathrm{~mL}$ Erlenmeyer flask. The initial $\mathrm{Cd}(\mathrm{II})$ concentration was $10 \mathrm{mg} \mathrm{L}^{-1}$, and the $\mathrm{pH}$ values were adjusted to 6. Samples were taken from the Erlenmeyer flask at the following intervals during the reaction: 0.17 , $0.33,0.5,1,2,6,12$ and $24 \mathrm{~h}$.

Effect of adsorbent dose: ATP and ATP-Al doses of $0.02,0.05,0.1,0.15,0.2,0.4$ and $0.5 \mathrm{~g}$ were added to $25 \mathrm{~mL}$ of a $\mathrm{Cd}(\mathrm{II})$ solution in $50 \mathrm{~mL}$ centrifuge tubes. The initial Cd(II) concentration was $10 \mathrm{mg} \mathrm{L}^{-1}$. The $\mathrm{pH}$ values of the solution were adjusted to 6 .

\section{Results and Discussion}

\section{TEM Analysis}

TEM was used to analyse the structural characteristics of ATP and ATP-Al (Fig. 1).

The ATP had a rod-like morphology and good dispersion (Fig. 1a). When ATP is modified by aluminium hydroxide, many small irregular fragments and amorphous matter appear around the rods (Fig. 1b). However, the length and aggregation state of ATP-Al rods do not evidently change. This indicated that aluminium hydroxide is wrapped on the rod and does not damage the crystal structure of ATP.

\section{XRD Spectra}

XRD can effectively analyse the change in crystal structure. The diffraction patterns of ATP and ATP-Al

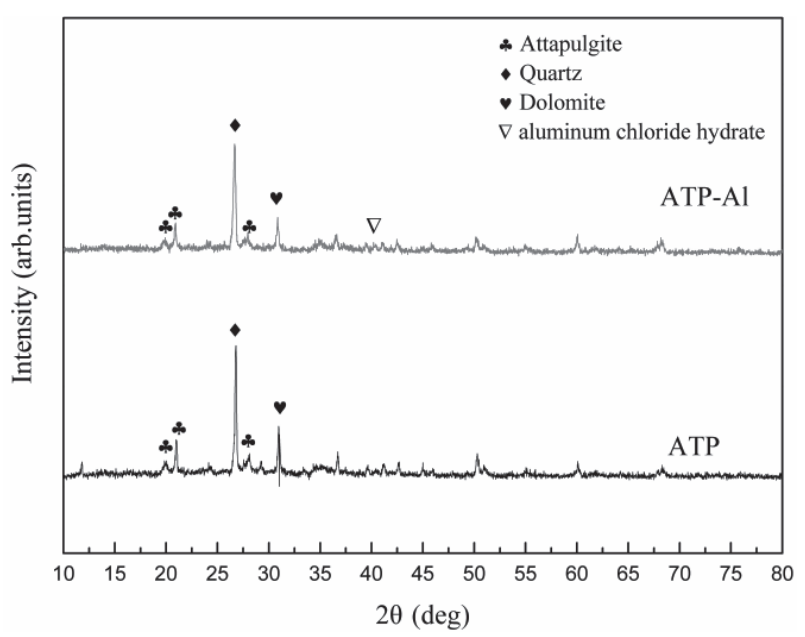

Fig. 2. XRD patterns of ATP and ATP-Al.

are shown in Fig. 2. The reflections at $2 \theta$ of 19.98, 20.8, $27.99^{\circ}$ are identified as attapulgite [22]. The reflections at $2 \theta$ values of 26.79 and $30.96^{\circ}$ represent quartz and dolomite, respectively [14, 23].

The XRD spectrum had no significant differences between ATP and ATP-Al, considering that aluminium hydroxide is amorphous and does not have a substantial effect on the crystal form [18]. However, a weak peak appeared at a $2 \theta$ of $40.36^{\circ}$ in the XRD spectrum of ATP-Al, which is assigned to aluminium chloride hydrate and is considered to be formed by residual aluminium chloride.

\section{FTIR Spectra}

Fig. 3 shows the FTIR spectra of ATP and ATPAl. The band at $3612 \mathrm{~cm}^{-1}$ is attributed to the stretching modes of $\mathrm{Mg}-\mathrm{OH}$, and the band at $3550 \mathrm{~cm}^{-1}$ is attributed to the stretching vibration of $\mathrm{Al}-\mathrm{Fe}^{3+}-\mathrm{OH}$ or Al-Mg-OH [24]. The vibration peak at $1651 \mathrm{~cm}^{-1}$ corresponds to the bending vibration modes of water molecules, which is attributed to adsorbed water $(\mathrm{HOH})$ [19]. The band at $1423 \mathrm{~cm}^{-1}$ is the vibration peak of
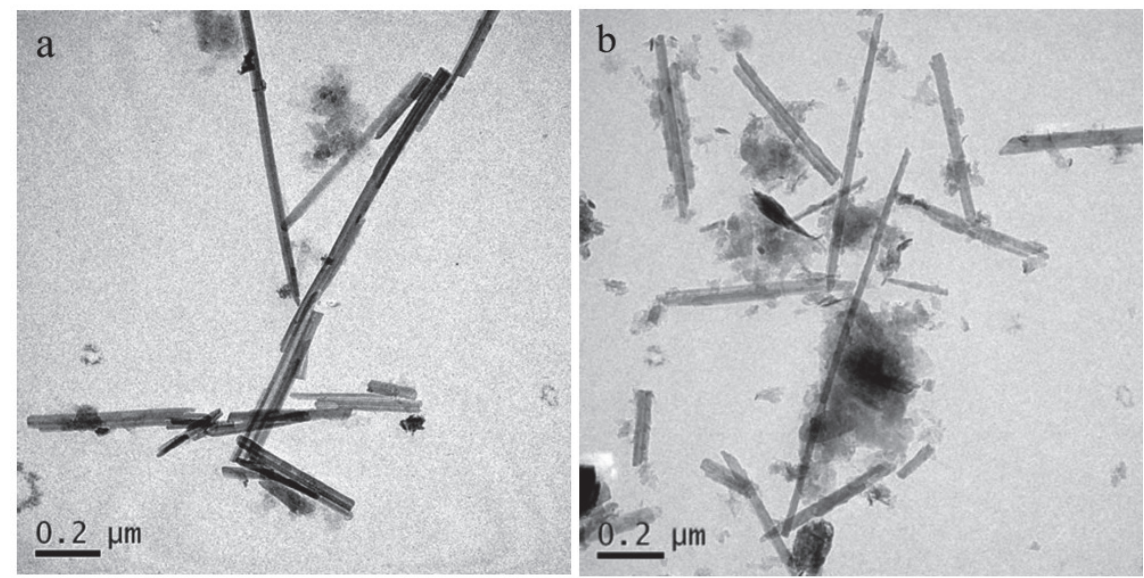

Fig. 1. TEM images of ATP and ATP-Al. 


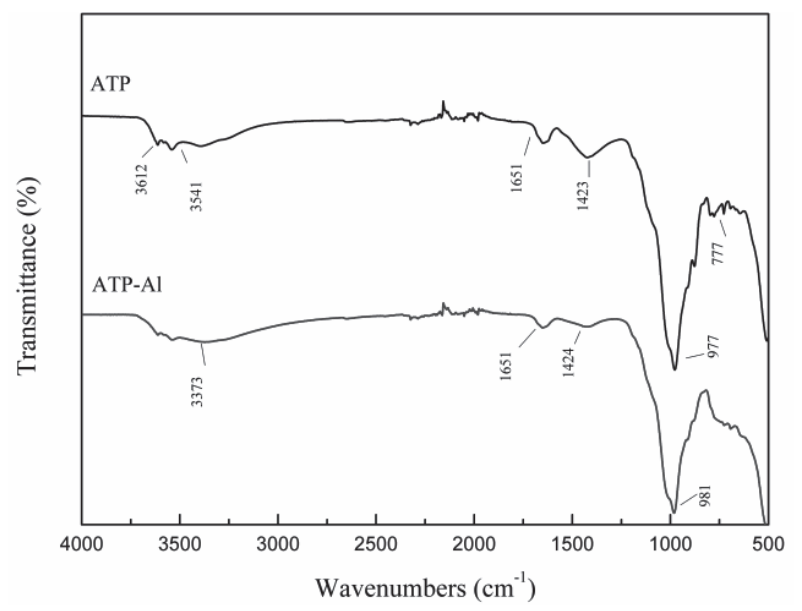

Fig. 3. FTIR patterns of ATP and ATP-Al.

carbonate, indicating that attapulgite contains carbonate minerals such as calcite and dolomite [25]. The band at $977 \mathrm{~cm}^{-1}$ is considered to be the stretching vibration of Si-O-M [24], and the band at $777 \mathrm{~cm}^{-1}$ is the vibration peak of Si-O-Si, which suggests the existence quartz of in ATP [26].

For ATP-Al, the band at $1423 \mathrm{~cm}^{-1}$ is weakened, indicating that the existence of carbonate in the attapulgite was eliminated. The band at $977 \mathrm{~cm}^{-1}$ is switched to $981 \mathrm{~cm}^{-1}$ and becomes weakened, which shows that $\mathrm{Si}-\mathrm{O}-\mathrm{M}$ is broken by $\mathrm{Al}^{3+}$. The disappearance of the band at $777 \mathrm{~cm}^{-1}$ indicated that $\mathrm{SiO}_{2}$ reacted with $\mathrm{Al}^{3+}$ to form $\mathrm{Si}-\mathrm{O}-\mathrm{Al}$ with a certain adsorption activity [27]. Two bands of ATP at $3612 \mathrm{~cm}^{-1}$ and $3541 \mathrm{~cm}^{-1}$ disappeared, and a broad band at $3373 \mathrm{~cm}^{-1}$ appeared due to the coordinated water for aluminium hydroxide [24].

\section{Effect of $\mathrm{pH}$}

The effect of $\mathrm{pH}$ was evaluated within the $\mathrm{pH}$ range of 3 to 7 for $\mathrm{Cd}(\mathrm{II})$ adsorption onto ATP and ATP-Al (Fig. 4). The $\mathrm{Q}_{\mathrm{e}}$ of the two adsorbents increased with increasing $\mathrm{pH}$ of the solution until the $\mathrm{pH}$ was 7, and the $\mathrm{Q}_{\mathrm{e}}$ reached a maximum. The $\mathrm{Q}_{\mathrm{e}}$ of ATP-Al was greater than that of ATP and increased drastically when the $\mathrm{pH}$ was in the range of 3 to 6 . The $\mathrm{Q}_{\mathrm{e}}$ of ATP increased more slowly from $\mathrm{pH} 3$ to 6 ; however, it increased drastically at $\mathrm{pH} 7$ and was close to that of ATP-Al. Because the final $\mathrm{pH}$ was weakly alkaline, Cd(II) underwent precipitation. Therefore, a rapid increase in $\mathrm{Q}_{\mathrm{e}}$ was observed for both adsorbents. To ensure that $\mathrm{Cd}(\mathrm{II})$ did not precipitate as a hydroxide due to a high solution $\mathrm{pH}$, we chose a $\mathrm{pH}$ value of 6 in this study.

When adsorption reached equilibrium, the $\mathrm{pH}$ values of the ATP adsorbent solution changed from 3, 4, 5, 6 and 7 to $6.18,6.45,6.55,6.60$ and 7.10 , respectively, and the $\mathrm{pH}$ values of the ATP-Al solution became 6.40, 6.59, 6.65, 6.70 and 7.30 (Fig. 5). This shows that the initial $\mathrm{pH}$ of the solution containing both adsorbents increased,

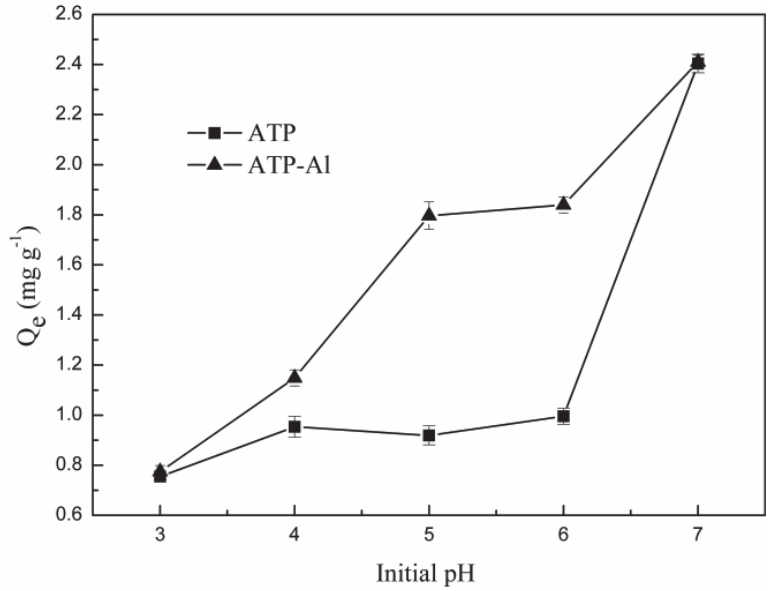

Fig. 4. Effect of initial $\mathrm{pH}$ on $\mathrm{Cd}(\mathrm{II})$ adsorption onto ATP and ATP-Al (error bars indicate standard error of the mean).

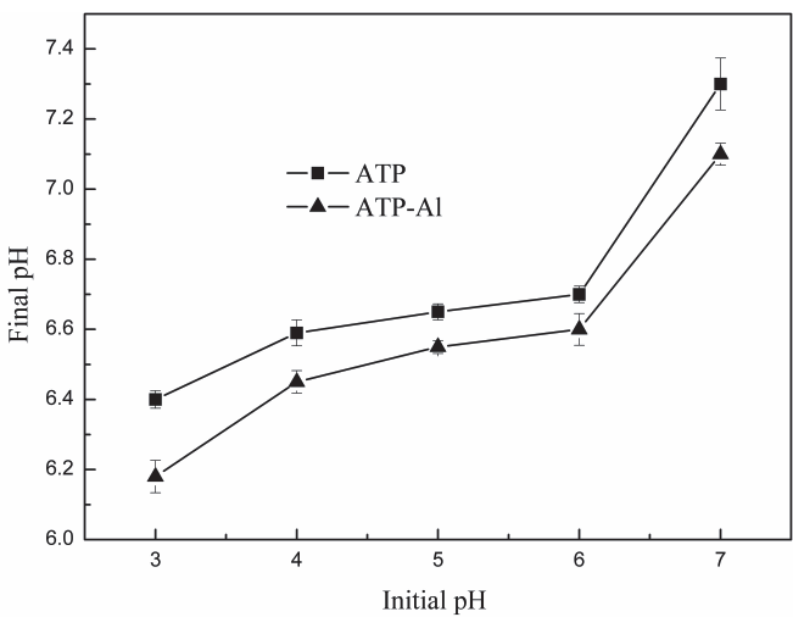

Fig. 5. The final $\mathrm{pH}$ after adsorption of $\mathrm{Cd}(\mathrm{II})$ onto ATP and ATP$\mathrm{Al}$ at different initial $\mathrm{pH}$ values (error bars indicate standard error of the mean).

and the increasing trend was almost consistent between adsorbents.

At a lower initial $\mathrm{pH}$ value, the silanol groups of ATP were easily protonated to form $\mathrm{SiOH}_{2}^{+}$, which can be represented by Eq. (2); therefore, their ability to adsorb $\mathrm{Cd}(\mathrm{II})$ was reduced. As the concentration of $\mathrm{H}^{+}$decreased in the solution, the final $\mathrm{pH}$ value of the solution increased. However, when the initial $\mathrm{pH}$ reached close to neutral, only a few protons competed with $\mathrm{Cd}(\mathrm{II})$, and the dominant reaction was electrostatic attraction between the adsorbent surface and $\mathrm{Cd}(\mathrm{II})$, which is represented by Eq. (3) [8]. As Cd(II) adsorption increased, some protons were released into the solution, causing the final $\mathrm{pH}$ to be slightly higher than the initial $\mathrm{pH}$.

$$
\mathrm{Si}-\mathrm{OH}+\mathrm{H}^{+} \rightarrow \mathrm{SiOH}_{2}^{+}
$$

$$
\mathrm{Si}-\mathrm{OH}+\mathrm{Cd}^{2+} \rightarrow \mathrm{Si}-\mathrm{OCd}^{+}+\mathrm{H}^{+}
$$




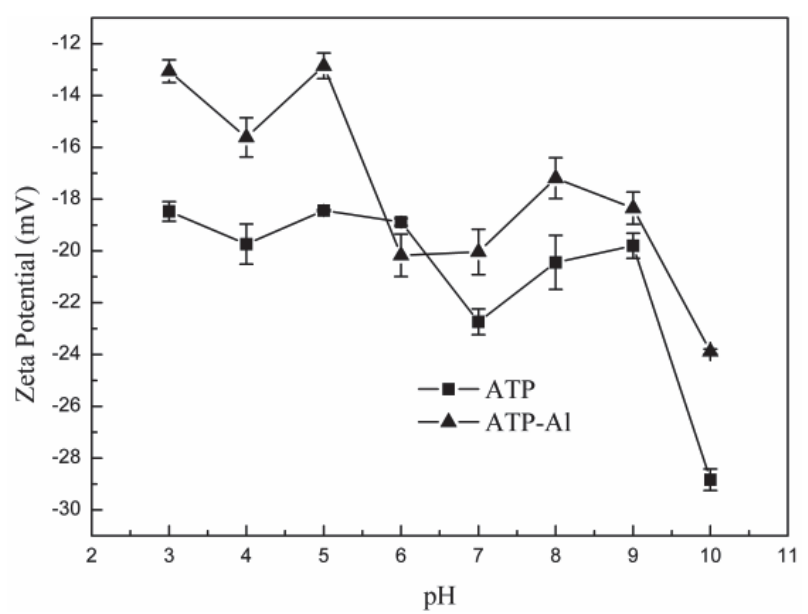

Fig. 6. Zeta potentials of ATP and ATP-Al at different $\mathrm{pH}$ values (error bars indicate standard error of the mean).

The Cd(II) adsorption process by silanol groups on the surface of ATP-Al was similar to that on the surface of ATP. However, aluminium hydroxide provided more active sites $(\mathrm{AlOH})$ on the surface of ATP-Al than were available on the surface of ATP. When the initial $\mathrm{pH}$ increased, the number of adsorption sites (AlO-) increased, as represented by Eq. (4). Moreover, the amount of adsorbed $\mathrm{Cd}(\mathrm{II})$ increases for more adsorption sites, as represented by Eq. (5) [28].

$$
\text { Attapugite-AlOH } \rightarrow \text { Attapugite- } \mathrm{AlO}^{-}+\mathrm{H}^{+}
$$

$$
\text { Attapugite-AlO }+\mathrm{Cd}^{2+} \rightarrow \text { Attapugite-AlOCd }{ }^{+}
$$

Therefore, silane group adsorption and hydroxyl group adsorption sites on ATP-Al facilitated Cd(II) adsorption.

The effect of $\mathrm{pH}$ on $\mathrm{Cd}(\mathrm{II})$ adsorption can be explained by the surface charge on ATP and ATP-Al. The Zeta potentials of ATP and ATP-Al at different $\mathrm{pH}$ values in the range of 3-10 were tested (Fig. 6). The results showed that ATP and ATP-Al were negatively charged with no isoelectric points. In comparison, ATP was more negative than ATP-Al in the $\mathrm{pH}$ range of 3-10. This indicates that the $\mathrm{Al}^{3+}$ ions on the surfaces of attapulgite gave rise to a lower Zeta potential [29].

It can be seen that ATP more easily binds metal cations; however, its adsorption capacity of $\mathrm{Cd}(\mathrm{II})$ is not as good as that of ATP-Al because more adsorption sites on the surface of ATP-Al are provided by aluminium hydroxide.

\section{Adsorption Isotherms}

The adsorption isotherms of $\mathrm{Cd}(\mathrm{II})$ adsorption onto ATP and ATP-Al are shown in Fig. 7. As the Cd(II) equilibrium concentration increased, the amount of Cd(II) adsorbed by both adsorbents also increased because the increase in $\mathrm{Cd}(\mathrm{II})$ concentration would

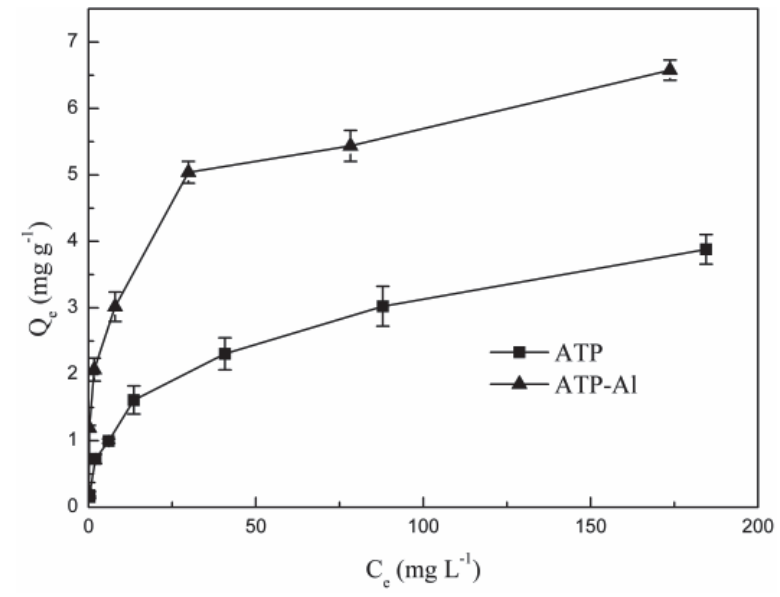

Fig. 7. Equilibrium isotherms of Cd(II) adsorption onto ATP and ATP-Al (error bars indicate standard error of the mean.)

improve the driving force at the solid-liquid interface, causing an increase in the amount of $\mathrm{Cd}(\mathrm{II})$ adsorbed onto the adsorbents [30]. At any $\mathrm{Cd}(\mathrm{II})$ equilibrium concentration, the $\mathrm{Q}_{\mathrm{e}}$ of ATP-Al was greater than that of ATP. This confirmed that the generation of more adsorption sites on ATP-Al was very favourable to the removal of $\mathrm{Cd}(\mathrm{II})$.

Fig. 8 shows that the final solution $\mathrm{pH}$ decreased with increasing initial $\mathrm{Cd}(\mathrm{II})$ concentration when the initial $\mathrm{pH}$ of the solution was 6 . When the initial $\mathrm{Cd}(\mathrm{II})$ concentration rose from 1 to $50 \mathrm{mg} \mathrm{L}^{-1}$, the final $\mathrm{pH}$ was significantly higher than the initial $\mathrm{pH}$ for both adsorbents. When the $\mathrm{Cd}(\mathrm{II})$ concentration increased from 50 to $200 \mathrm{mg} \mathrm{L}^{-1}$, the final $\mathrm{pH}$ was slightly higher than the initial $\mathrm{pH}$ for both adsorbents. The following fact can explain the reasoning. At lower initial Cd(II) concentrations, the main reaction was the silanol groups of adsorbents protonated to form $\mathrm{SiOH}^{2+}$, which can be represented by Eq. (2). As the concentration of $\mathrm{H}^{+}$

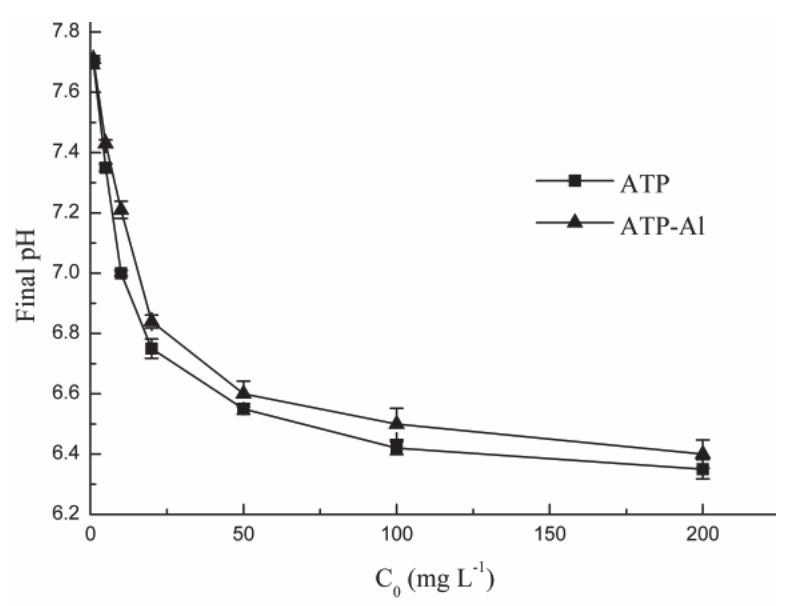

Fig. 8. The final $\mathrm{pH}$ after adsorption onto ATP and ATP-Al at different initial $\mathrm{Cd}$ (II) concentrations (error bars indicate standard error of the mean). 


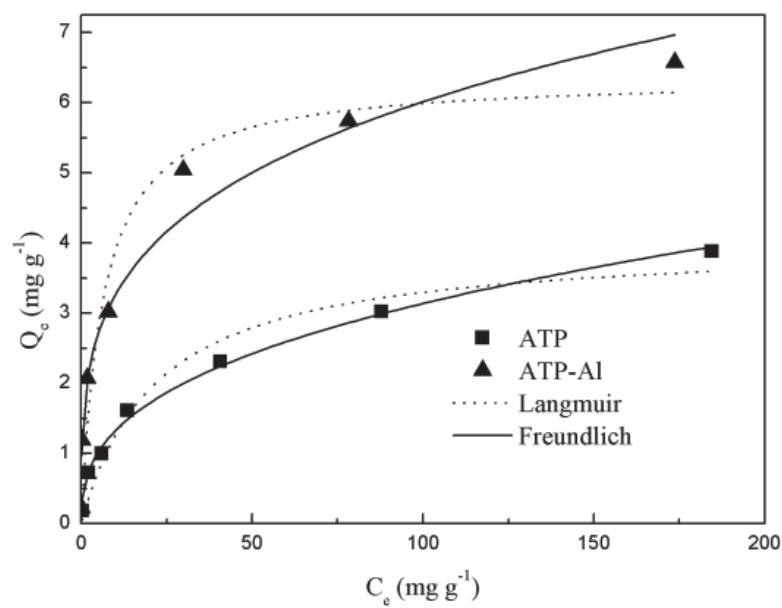

Fig. 9. Langmuir and Freundlich isotherm plots of $\mathrm{Cd}(\mathrm{II})$ adsorption onto ATP and ATP-Al.

decreased in the solution, the final $\mathrm{pH}$ was evidently higher than the initial $\mathrm{pH}$ of the solution for both adsorbents. When the initial $\mathrm{Cd}(\mathrm{II})$ concentration increased, the amounts of $\mathrm{Cd}(\mathrm{II})$ competed with $\mathrm{H}^{+}$, and the dominant reaction was electrostatic attraction between the adsorbent surface and $\mathrm{Cd}(\mathrm{II})$, which is represented by Eq. (3) [8]. Some $\mathrm{H}^{+}$entered the solution, resulting in a final $\mathrm{pH}$ slightly higher than the initial $\mathrm{pH}$ in the solution [30].

The Langmuir model and Freundlich model were used to analyse ATP and ATP-Al for the adsorption of $\mathrm{Cd}(\mathrm{II})$. The Langmuir model assumes that there is only one type of adsorption site, and the number of sites is limited. Furthermore, monolayer sorption occurred on the surface of the adsorbent [31]. The Freundlich equation assumes that adsorption occurs on a heterogeneous surface [32]. The two models are described in Eq. (6) and Eq. (7). The fitting curves are shown in Fig. 9.

$$
\begin{aligned}
& \mathrm{Q}_{\mathrm{e}}=\frac{\mathrm{Q}_{\mathrm{m}} \mathrm{K}_{\mathrm{L}} \mathrm{C}_{\mathrm{e}}}{1+\mathrm{K}_{\mathrm{L}} \mathrm{C}_{\mathrm{e}}} \\
& \mathrm{Q}_{\mathrm{e}}=\mathrm{K}_{\mathrm{f}} \mathrm{C}_{\mathrm{e}}^{1 / \mathrm{n}}
\end{aligned}
$$

...where $\mathrm{Q}_{\mathrm{m}}$ and $\mathrm{Q}_{\mathrm{e}}$ are the maximum adsorption capacity and the equilibrium capacity of $\mathrm{Cd}(\mathrm{II})\left(\mathrm{mg} \mathrm{g}^{-1}\right)$, respectively. $\mathrm{C}_{\mathrm{e}}$ is the $\mathrm{Cd}(\mathrm{II})$ equilibrium concentration (mg L-1), $\mathrm{K}_{\mathrm{L}}$ and $\mathrm{K}_{\mathrm{f}}$ are the Langmuir adsorption constant $\left(\mathrm{L} \mathrm{mg}^{-1}\right)$ and the Freundlich constant $\left(\mathrm{L} \mathrm{g}^{-1}\right)$, respectively, and $1 / \mathrm{n}$ is the heterogeneity factor.

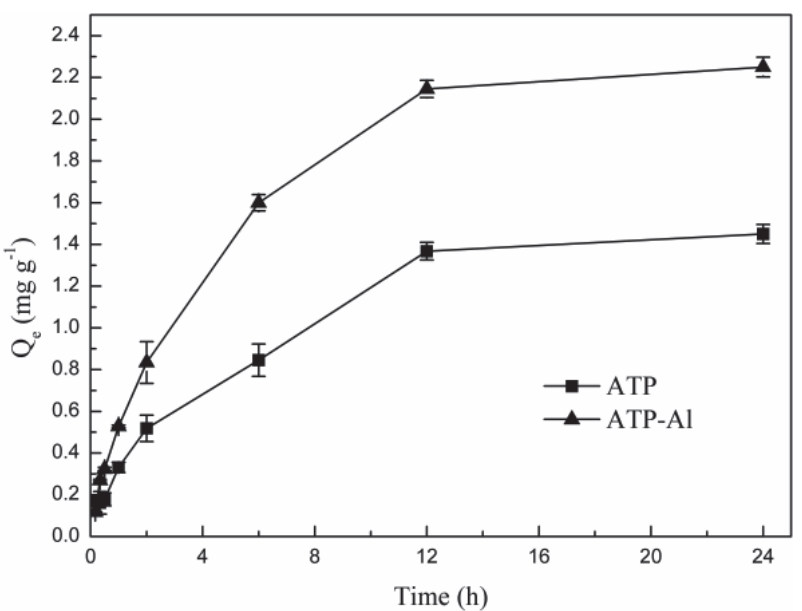

Fig. 10. Effect of contact time on Cd(II) adsorption onto ATP and ATP-Al (error bars indicate standard error of the mean).

Table 1 lists the parameters calculated by the two models. The correlation coefficients $\left(\mathrm{r}^{2}\right)$ for ATP and ATP-Al adsorption fitting by the Langmuir model were 0.955 and 0.932 , respectively. The correlation coefficients $\left(\mathrm{r}^{2}\right)$ of the Freundlich model for ATP and ATP-Al were 0.992 and 0.959 , respectively. Because the values of $r^{2}$ from the Freundlich model were higher than those of the Langmuir model for ATP and ATP-Al, we believed that the Freundlich model better described the adsorption of $\mathrm{Cd}(\mathrm{II})$ onto ATP and ATP-Al.

The maximum adsorption capacity $\mathrm{Q}_{\mathrm{m}}$ of ATP and ATP-Al was 4.01 and $6.36 \mathrm{mg} \mathrm{g}^{-1}$, respectively, as calculated by the Langmuir model.

\section{Adsorption Kinetics}

Fig. 10 shows the contact time influence on the adsorption of $\mathrm{Cd}(\mathrm{II})$ onto ATP and ATP-Al. The adsorption capacity of the two adsorbents rapidly increased with time. After $12 \mathrm{~h}$, the adsorption capacity reached equilibrium. During the whole adsorption process, the adsorption of $\mathrm{Cd}(\mathrm{II})$ by ATP-Al was greater than that of ATP. The equilibrium $\mathrm{Cd}(\mathrm{II})$ adsorption capacities $\left(\mathrm{Q}_{\mathrm{e}, \mathrm{exp}}\right)$ of ATP and ATP-Al obtained from experiments were 1.40 and $2.20 \mathrm{mg} \mathrm{g}^{-1}$, respectively.

The $\mathrm{pH}$ of the solution increased with increasing reaction time when the initial $\mathrm{pH}$ was 6 (Fig. 11). The adsorption reached equilibrium at $12 \mathrm{~h}$, and the final $\mathrm{pH}$ of the solution containing ATP-Al was higher than the final $\mathrm{pH}$ of the solution containing ATP. The curve of change of $\mathrm{pH}$ is similar to Fig. 10. This may be due to

Table 1. Fitting results of adsorption isotherms.

\begin{tabular}{|c|c|c|c|c|c|c|}
\hline & \multicolumn{3}{|c|}{ Langmuir } & \multicolumn{3}{c|}{ Freundlich } \\
\cline { 2 - 7 } & $\mathrm{Q}_{\mathrm{m}}\left(\mathrm{mg} \mathrm{g}^{-1}\right)$ & $\mathrm{K}_{\mathrm{L}}\left(\mathrm{L} \mathrm{mg}^{-1}\right)$ & $\mathrm{r}^{2}$ & $\mathrm{~K}_{\mathrm{f}}\left(\mathrm{L} \mathrm{g}^{-1}\right)$ & $1 / \mathrm{n}$ & $\mathrm{r}^{2}$ \\
\hline ATP & 4.01 & 0.045 & 0.955 & 0.56 & 0.374 & 0.992 \\
\hline ATP-A1 & 6.36 & 0.157 & 0.932 & 1.76 & 0.265 & 0.959 \\
\hline
\end{tabular}




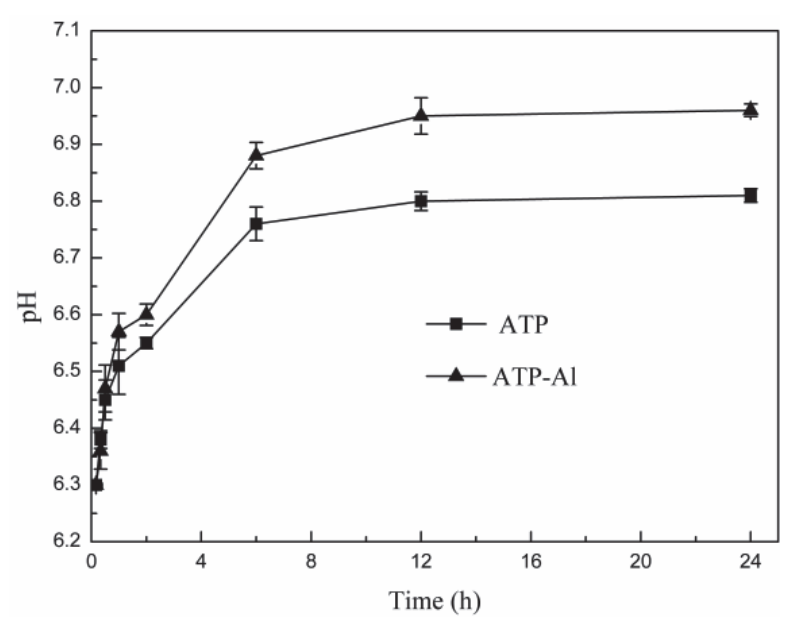

Fig. 11. Solution $\mathrm{pH}$ during $\mathrm{Cd}(\mathrm{II})$ adsorption onto ATP and ATP-Al for different contact times (error bars indicate standard error of the mean).

the following reasons. The initial Cd (II) concentration was lower, and more $\mathrm{H}^{+}$was adsorbed onto the surface of ATP and ATP-Al, resulting in an increase in the solution $\mathrm{pH}$. However, ATP-Al had more adsorption sites than ATP, so more $\mathrm{H}^{+}$and $\mathrm{Cd}(\mathrm{II})$ in solution were adsorbed by ATP-Al. The $\mathrm{Cd}(\mathrm{II})$ adsorption capacity and final $\mathrm{pH}$ were higher than those of ATP.

To investigate the adsorption mechanism of ATP and ATP-Al, we used pseudo-first-order (Eq. (8)) and pseudo-second-order (Eq. (9)) kinetics in their linearized forms to fit the experimental data.

$$
\begin{gathered}
\log \left(Q_{e}-Q_{t}\right)=\log \left(Q_{e}\right)-\frac{\left(k_{1} t\right)}{2.303} \\
\frac{t}{Q_{t}}=\frac{1}{\left(k_{2} Q_{e}^{2}\right)}+\frac{t}{Q_{e}}
\end{gathered}
$$

...where $\mathrm{Q}_{\mathrm{t}}$ is the $\mathrm{Cd}(\mathrm{II})$ adsorption capacity at a reaction time $(\mathrm{t}),\left(\mathrm{mg} \mathrm{g}^{-1}\right) ; \mathrm{Q}_{\mathrm{e}}$ is the equilibrium capacity of $\mathrm{Cd}(\mathrm{II}),\left(\mathrm{mg} \mathrm{g}^{-1}\right)$; and $\mathrm{k}_{1}$ and $\mathrm{k}_{2}$ are the rate constants of pseudo-first-order $\left(\mathrm{h}^{-1}\right)$ and pseudo-second-order ( $\mathrm{g}$ $\left.\mathrm{mg}^{-1} \mathrm{~h}^{-1}\right)$, respectively. Then, $\log \left(\mathrm{Q}_{\mathrm{e}}-\mathrm{Q}_{\mathrm{t}}\right)$ versus $\mathrm{t}$ was used to plot a straight line, and $\mathrm{k}_{1}$ was calculated by the intercept and slope (Fig. 12a). $t / Q_{t}$ versus $t$ plotted to another straight line, and $\mathrm{k}_{2}$ was calculated in the same manner (Fig. 12b).

The calculated parameters are shown in Table 2 . The correlation coefficients $\left(\mathrm{r}^{2}\right)$ for ATP and ATP$\mathrm{Al}$ adsorption fitting by the pseudo pseudo-first-order model were 0.8800 and 0.8980 , respectively. The correlation coefficients $\left(\mathrm{r}^{2}\right)$ of the pseudo-second-order model of $\mathrm{Cd}(\mathrm{II})$ adsorption onto ATP and ATP-Al were 0.9752 and 0.9941 , respectively. The correlation coefficient values of the pseudo-second-order model for ATP and ATP-Al were very high.

The $\mathrm{Q}_{\mathrm{e}}\left(\mathrm{Q}_{\mathrm{e}, \mathrm{cal}}\right)$ values calculated by the pseudosecond-order kinetic model were close to the $\mathrm{Q}_{\mathrm{e}, \exp }$ values.

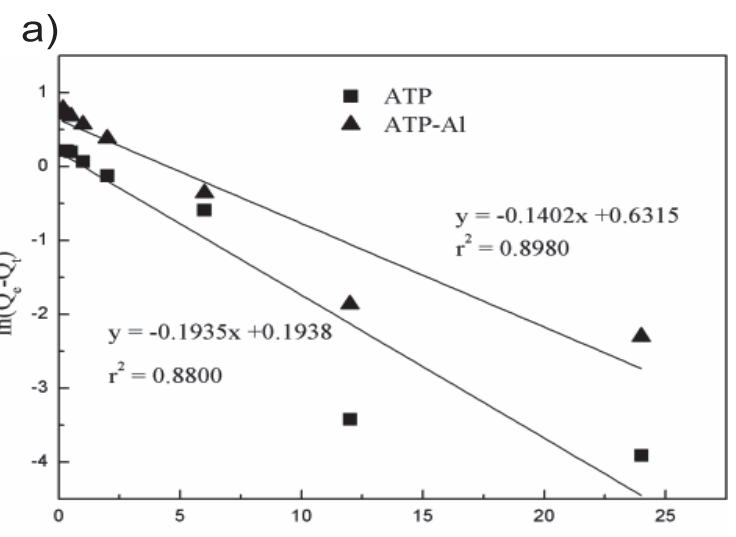

b)

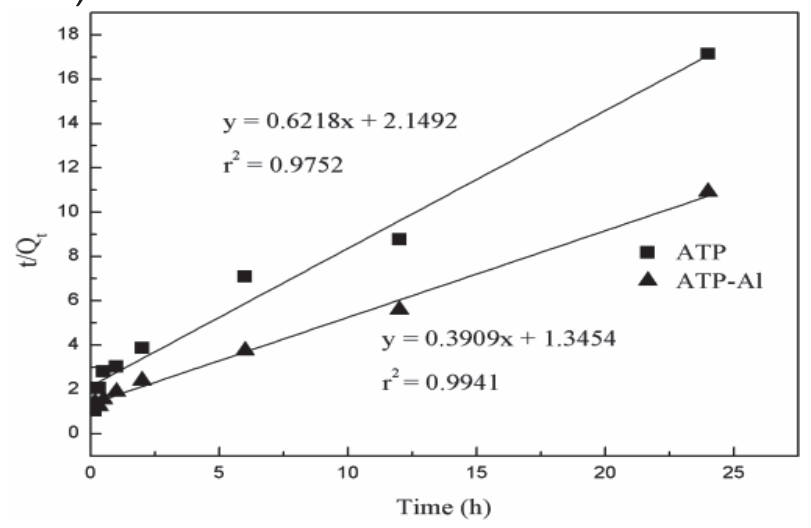

Fig. 12. Kinetic models of Cd(II) adsorption onto ATP and ATP$\mathrm{Al}:$ a) pseudo-first-order model; b) pseudo-second-order model.

It was clearly revealed that the adsorption kinetics of Cd(II) onto ATP and ATP-Al can be described well by the pseudo-second-order adsorption model best fit.

The best fit between the pseudo-first-order and pseudo-second-order models is evaluated by the Chisquare test $\left(\chi^{2}\right)$ and the sum of the squares of errors (SSE) [33].

The form of $\chi^{2}$ and SSE can be expressed as Eq. (10) and Eq. (11), respectively.

$$
\begin{gathered}
\chi^{2}=\sum \frac{\left(\mathrm{q}_{\mathrm{e}, \text { theor }}-\mathrm{q}_{\mathrm{e}, \text { meas }}\right)^{2}}{\mathrm{q}_{\mathrm{e}, \text { theor }}} \\
\mathrm{SSE}=\sum\left(\mathrm{q}_{\mathrm{e}, \text { theor }}-\mathrm{q}_{\mathrm{e}, \text { meas }}\right)^{2}
\end{gathered}
$$

...where $\mathrm{q}_{\mathrm{e} \text {,meas }}$ is the experimental equilibrium capacity $\left(\mathrm{mg} \mathrm{g}^{-1}\right)$ and $\mathrm{q}_{\mathrm{e} \text {,theor }}$ is the theoretical equilibrium capacity from the model. $\chi^{2}$ values are small that stand for $\mathrm{q}_{\mathrm{e} \text {,theor }}$ similar to $\mathrm{q}_{\mathrm{e} \text {,meas }}$; if they differ, $\chi^{2}$ values will be large.

The $\chi^{2}$ and SSE values of ATP for pseudo-secondorder are 0.022 and 0.036 lower than those of pseudofirst-order, respectively. The $\chi^{2}$ and SSE values of ATP-Al for pseudo-second-order are 0.026 and 0.068 lower than those of pseudo-first-order. This confirmed that $\mathrm{Cd}(\mathrm{II})$ adsorption on ATP and ATP-Al follows the pseudo-second-order model. The parameters are listed in Table. 3 . 
Table 2. Fitting parameters of adsorption kinetics.

\begin{tabular}{|c|c|c|c|c|c|c|c|}
\hline \multirow{2}{*}{} & \multirow{2}{*}{$\mathrm{Q}_{\mathrm{e}, \mathrm{exp}}\left(\mathrm{mg} \mathrm{g}^{-1}\right)$} & \multicolumn{3}{|c|}{ Pseudo-first-order } & \multicolumn{3}{c|}{ Pseudo-second-order } \\
\cline { 3 - 9 } & & $\mathrm{Q}_{\mathrm{e}, \mathrm{cal}}\left(\mathrm{mg} \mathrm{g}^{-1}\right)$ & $\mathrm{k}_{1}\left(\mathrm{~h}^{-1}\right)$ & $\mathrm{r}^{2}$ & $\mathrm{Q}_{\mathrm{e}, \mathrm{cal}}\left(\mathrm{mg} \mathrm{g}^{-1}\right)$ & $\mathrm{k}_{2}\left(\mathrm{~g} \mathrm{mg}^{-1} \mathrm{~min}^{-1}\right)$ & $\mathrm{r}^{2}$ \\
\hline ATP & 1.42 & 1.21 & 0.4456 & 0.8800 & 1.61 & 0.1795 & 0.9752 \\
\hline ATP-Al & 2.30 & 1.88 & 0.3228 & 0.8980 & 2.56 & 0.1134 & 0.9941 \\
\hline
\end{tabular}

\section{Thermodynamics Studies}

The change in adsorption rate at different temperatures will determine whether the process is endothermic or exothermic.

The following equations Eq. (12) and Eq. (13) can calculate the thermodynamic parameters such as Gibbs free energy $\left(\Delta \mathrm{G}^{\circ}\right)$, entropy $\left(\Delta \mathrm{S}^{\circ}\right)$ and enthalpy $\left(\Delta \mathrm{H}^{\circ}\right)$ [34]:

$$
\begin{gathered}
\Delta G^{\circ}=-R T \ln K_{d} \\
\ln \left(K_{d}\right)=-\frac{\Delta H^{\circ}}{R T}+\frac{\Delta S^{\circ}}{R}
\end{gathered}
$$

...where $\mathrm{R}$ is the gas constant $\left(8.314 \mathrm{~J} \mathrm{~mol}^{-1} \mathrm{~K}^{-1}\right)$, $\mathrm{T}$ is the temperature of the adsorption process $(\mathrm{K}), \mathrm{K}_{\mathrm{d}}$ is the equilibrium constant obtained from the Langmuir isotherm constant and $\mathrm{K}_{\mathrm{d}}=1 / \mathrm{K}_{\mathrm{L}}\left(\mathrm{L} \mathrm{mg}^{-1}\right)$ [34]. $\mathrm{Ln}\left(\mathrm{K}_{\mathrm{d}}\right)$ versus $1 / \mathrm{T}$ plotted a straight line and obtained $\Delta \mathrm{H}^{\circ}$ and $\Delta \mathrm{S}^{\circ}$ through the slope and intercept, respectively. The thermodynamic parameters of ATP and ATP-Al for $\mathrm{Cd}(\mathrm{II})$ adsorption are listed in Table. 4.

The $\Delta \mathrm{G}^{\circ}$ values of ATP and ATP-Al are all negative, which means that the adsorption is spontaneous in the temperature range of 293 to $313 \mathrm{~K}$. The $\Delta \mathrm{G}^{\circ}$ increased with increasing temperature for $\mathrm{Cd}(\mathrm{II})$ adsorption on the two adsorbents, which indicates that the adsorption process on the two adsorbents became less spontaneous at higher temperatures. The $\Delta \mathrm{G}^{\circ}$ values are in the range of -20 to $0 \mathrm{~kJ} \mathrm{~mol}^{-1}$, indicating that the adsorption

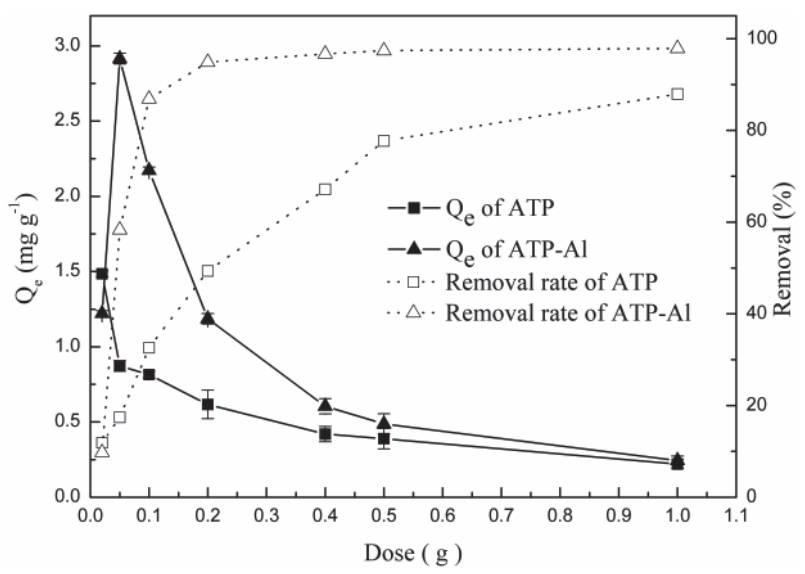

Fig. 13. Effect of adsorbent dose on Cd(II) removal (error bars indicate standard error of the mean). process of the two adsorbents is physisorption [35].

The $\Delta \mathrm{H}^{\circ}$ values for $\mathrm{Cd}(\mathrm{II})$ adsorption on ATP and ATP-Al were $-20.78 \mathrm{~kJ} \mathrm{~mol}^{-1}$ and $-49.49 \mathrm{~kJ} \mathrm{~mol}^{-1}$, respectively, indicating that the adsorption process was exothermic. The $\Delta \mathrm{S}^{\circ}$ values for adsorption of $\mathrm{Cd}(\mathrm{II})$ on ATP and ATP-Al were $-45.38 \mathrm{~J} \mathrm{~mol}^{-1} \mathrm{~K}^{-1}$ and $-147.91 \mathrm{~J} \mathrm{~mol}^{-1} \mathrm{~K}^{-1}$, respectively, refer to the ordered adsorption system [36].

\section{Effect of Adsorbent Dose}

The $\mathrm{Q}_{\mathrm{e}}$ and removal rate of $\mathrm{Cd}(\mathrm{II})$ are affected by ATP and ATP-Al doses (Fig. 13). The $\mathrm{Q}_{\mathrm{e}}$ decreased with increasing adsorbent dose of both ATP and ATP-Al. In contrast, the removal rate of $\mathrm{Cd}(\mathrm{II})$ increased with increasing adsorbent dose, and the $\mathrm{Cd}(\mathrm{II})$ removal rate of ATP-Al was higher than that of ATP. When the dose of ATP-Al was in the range of 0.02-0.1 g, the removal rate of $\mathrm{Cd}(\mathrm{II})$ was significantly increased, and when the dose was beyond $0.1 \mathrm{~g}$, the removal rate of $\mathrm{Cd}(\mathrm{II})$ was close to $95 \%$. Therefore, we believed that the optimal dose of ATP-Al was $0.1 \mathrm{~g}$ per $25 \mathrm{~mL}$ of solution $(4 \mathrm{~g} / \mathrm{L})$.

Fig. 14 shows that the initial $\mathrm{pH}$ of the solution was 6 , and the final solution $\mathrm{pH}$ increased with increasing adsorbent dose. This may be attributed to an increase in adsorption sites on the surface of ATP and ATP-Al that can adsorb more $\mathrm{H}^{+}$and result in an increase in the $\mathrm{pH}$ of the final solution [13].

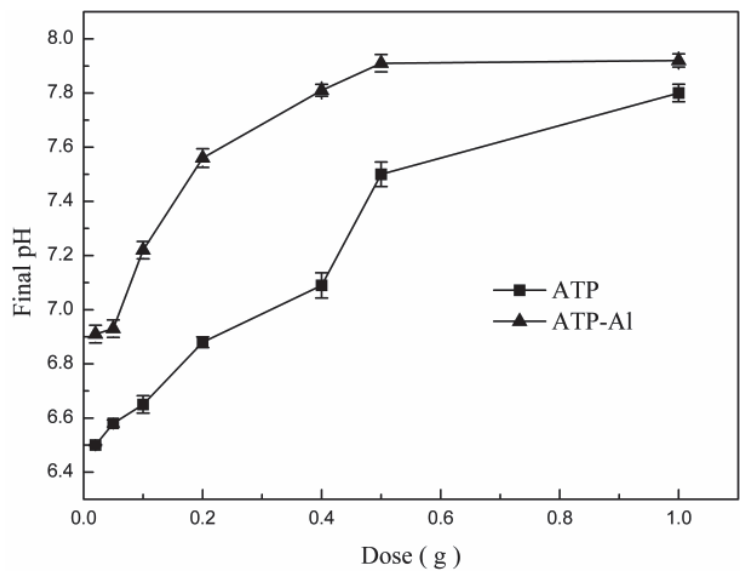

Fig. 14. The final $\mathrm{pH}$ after adsorption onto ATP and ATP-Al at different adsorbent doses (error bars indicate standard error of the mean). 
Table 3. Kinetic parameters for adsorption of $\mathrm{Cd}(\mathrm{II})$ analysis Error function used for parameter determination.

\begin{tabular}{|c|c|c|c|}
\hline \multicolumn{2}{|c|}{} & Pseudo-first-order & Pseudo-second-order \\
\hline \multirow{2}{*}{ ATP } & $\chi^{2}$ & 0.036 & 0.022 \\
\cline { 2 - 4 } & SSE & 0.044 & 0.036 \\
\hline \multirow{2}{*}{ ATP-Al } & $\chi^{2}$ & 0.093 & 0.026 \\
\cline { 2 - 4 } & SSE & 0.176 & 0.068 \\
\hline
\end{tabular}

\section{Adsorption Mechanisms}

In this study, aluminium hydroxide was coated on the surface of ATP, forming a new adsorbent ATP-Al. The TEM image shows that amorphous aluminium hydroxide was coated on the rod crystals of attapulgite. The crystal form of rods had no evident change after modification, which was confirmed by XRD. FTIR spectra showed that $\mathrm{Si}-\mathrm{O}-\mathrm{M}$ and $\mathrm{SiO}_{2}$ reacted with $\mathrm{Al}^{3+}$ to form $\mathrm{Si}-\mathrm{O}-\mathrm{Al}$ with a certain adsorption activity. The number of Al-OH groups was also increased by aluminium hydroxide.

In general, the $\mathrm{Cd}(\mathrm{II})$ adsorbed on attapulgite could be attributed to the mechanism including complexation, ion-exchange and precipitation [16]. For ATP-Al, the silanol groups $(\mathrm{Si}-\mathrm{OH})$ and $(\mathrm{Al}-\mathrm{OH})$ can form complex ions described by a surface complexation model, represented by Eq. (3) and Eq. (5).
Cation exchange would increase the value of $\mathrm{pH}$ in solution for the lower hydrolysis constant of $\mathrm{Cd}(\mathrm{II})$, represented by Eq. (14) [13].

ClayM $^{\mathrm{n}+}+\mathrm{Cd}^{2+} \leftrightarrow$ ClayCd $^{2+}+\mathrm{M}^{\mathrm{n}+}(\mathrm{M}=\mathrm{Ca}, \mathrm{K}, \mathrm{Mg}$, etc. $)$

The precipitation process can be neglected. Although the final $\mathrm{pH}$ value of the solution increases after adsorption, it does not reach the $\mathrm{pH}$ value required for Cd(II) precipitation.

The results indicate that the important mechanisms of complexation and exchange together influence $\mathrm{Cd}(\mathrm{II})$ adsorption on ATP-Al.

The Zeta potential values of ATP and ATP-Al were expected to indicate that $\mathrm{Cd}(\mathrm{II})$ had a strong affinity for the two adsorbents. The Zeta potential of ATP-Al was less negative than that of ATP at $\mathrm{pH}$ values from 3 to 10 , which was attributed to $\mathrm{Al}^{3+}$ on the surfaces of attapulgite giving rise to a lower Zeta potential. However, the adsorption of Cd(II) on ATP-Al was still higher than that on ATP. The reason was that there are more adsorption sites (Al-OH) on the surface of ATP$\mathrm{Al}$, which improves the adsorption of $\mathrm{Cd}(\mathrm{II})$.

\section{Comparison with Other Clays}

The Cd(II) adsorption capacity and equilibrium time for clay varied due to the properties of the absorbents

Table 4. Thermodynamic parameters of ATP and ATP-Al for Cd (II) adsorption.

\begin{tabular}{|c|c|c|c|c|c|c|}
\hline & $\mathrm{T}(\mathrm{K})$ & $\mathrm{K}_{\mathrm{d}}\left(\mathrm{L} \mathrm{mg}^{-1}\right)$ & $\mathrm{LnK}_{\mathrm{d}}$ & $\Delta \mathrm{H}^{\circ}\left(\mathrm{kJ} \mathrm{mol}^{-1}\right)$ & $\Delta \mathrm{S}^{\circ}\left(\mathrm{J} \mathrm{mol}^{-1} \mathrm{~K}^{-1}\right)$ & $\Delta \mathrm{G}^{\circ}\left(\mathrm{kJ} \mathrm{mol}^{-1}\right)$ \\
\hline \multirow{3}{*}{ ATP } & 293 & 20.83 & 3.037 & \multirow{3}{*}{-20.78} & \multirow{3}{*}{-45.38} & -7.40 \\
\hline & 303 & 17.60 & 2.867 & & & -7.22 \\
\hline & 313 & 12.04 & 2.489 & & & -6.48 \\
\hline \multirow{3}{*}{ ATP-Al } & 293 & 12.50 & 2.525 & \multirow{3}{*}{-49.49} & \multirow{3}{*}{-147.91} & -6.15 \\
\hline & 303 & 6.37 & 1.851 & & & -4.66 \\
\hline & 313 & 3.41 & 1.228 & & & -3.19 \\
\hline
\end{tabular}

Table 5. Compared with different raw clay and modified clay for Cd(II) adsorption capacity.

\begin{tabular}{|c|c|c|c|c|c|c|}
\hline \multicolumn{2}{|c|}{ Materials } & Adsorption capacity $\left(\mathrm{mg} \mathrm{g}^{-1}\right)$ & Equilibrium time $(\mathrm{h})$ & $\mathrm{pH}$ & Temperature $(\mathrm{K})$ & Reference \\
\hline \multirow{5}{*}{ Raw } & Attapulgite & 4.54 & 1.5 & 6 & 295 & {$[8]$} \\
\cline { 2 - 8 } & Kaolinite & 0.88 & 0.5 & - & 303 & {$[37]$} \\
\cline { 2 - 8 } & Zeolite & 4.01 & 2 & 5.5 & 298 & {$[38]$} \\
\cline { 2 - 8 } & ATP & 4.01 & 12 & 6 & 303 & In this work \\
\hline \multirow{5}{*}{ Modified } & MAP-ATP & 121 & 1 & 5.45 & 303 & {$[16]$} \\
\cline { 2 - 8 } & MnO-Kaol & 36.47 & 0.5 & 5 & 303 & {$[39]$} \\
\cline { 2 - 8 } & MgO-ATP & 25.30 & 1.5 & 5 & 298 & {$[40]$} \\
\cline { 2 - 7 } & ATP-Al & 6.32 & 12 & 6 & 303 & In this work \\
\hline
\end{tabular}


and the experimental conditions [16]. The adsorption capacity and equilibrium time for clays and inorganic modified clays were compared, and the data are listed in Table 5. The adsorption capacity of ATP is close to that of attaplugite studied by Alvarez [8]. However, it had a longer equilibrium time for adsorption. This may be related to the difference in materials from different origins.

The adsorption capacity of ATP-Al is much lower than that of other modified clays. The reason is that other inorganic modified clays had been calcined at a high temperature. The calcination evidently improved the adsorption capacity [13]. In this study, our purpose is to understand the influence of inorganic aluminium hydroxide on the adsorption performance of attapulgite without calcination.

\section{Conclusions}

From this study, we obtained the following conclusions:

(1) The synthesized ATP-Al exhibited better Cd(II) removal performance than that of natural ATP because aluminium hydroxide provides more adsorption sites onto the surface of ATP-Al.

(2) The Cd(II) adsorption capacity onto ATP and ATP-Al increased with increasing $\mathrm{pH}$, initial $\mathrm{Cd}(\mathrm{II})$ concentration and contact time. The adsorption capacity of the two adsorbents was highest at a solution $\mathrm{pH}$ of 7 . The adsorption process reached equilibrium after $12 \mathrm{~h}$.

(3) The Freundlich model best described the adsorption isotherm for Cd(II) adsorption onto both adsorbents. The maximum $\mathrm{Cd}(\mathrm{II})$ adsorption capacity calculated by the Langmuir model was 4.01 and 6.36 $\mathrm{mg} \mathrm{g}^{-1}$ on ATP and ATP-Al, respectively.

(4) The correlation coefficients of the pseudosecond-order model for ATP and ATP-Al were both high. Moreover, the $\mathrm{Q}_{\mathrm{e}, \mathrm{cal}}$ value calculated by the pseudo-second-order model was in good agreement with the experimental adsorption capacity $\left(\mathrm{Q}_{\mathrm{e} \text { exp }}\right)$. It was considered that the adsorption of $\mathrm{Cd}(\mathrm{II})$ onto ATP and ATP-Al follows pseudo-second-order kinetics.

(5) The effect of adsorbent dose shows that the optimal dose of ATP-Al was $0.1 \mathrm{~g}$ per $25 \mathrm{~mL}$ of solution $(4 \mathrm{~g} / \mathrm{L})$.

(6) The thermodynamic parameters indicated that the adsorption process is spontaneous, exothermic and mainly based on physical adsorption.

\section{Acknowledgements}

This work was supported by the Shengtongsheng Technology Innovation Fund of Gansu Agricultural University (No. GSAU-STS-2018-20).

\section{Conflict of Interest}

The authors declare no conflict of interest.

\section{References}

1. ZHONG Q.H., ZHOU Y.C., TSANG D.C.W., LIU J., YANG X., Y M.L., WU S.J., WANG J., XIAO T.F., ZHANG Z.F. Cadmium isotopes as tracers in environmental studies: A review. Science of The Total Environment, 736, 139585, 2020.

2. RAHMI., LELIFAJRI., JULINAWATI., SHABRINA. Preparation of chitosan composite film reinforced with cellulose isolated from oil palm empty fruit bunch and application in cadmium ions removal from aqueous solutions. Carbohydrate Polymers, 170, 226, 2017.

3. JADHAV U.U., HOCHENG H. Removal of nickel and cadmium from battery waste by a chemical method using ferric sulphate. Environmental Technology, 35 (10), 1263, 2014.

4. YANG W., REN N.Q., LI G.B. Hydrous Manganese Dioxide Enhanced Ferric Chloride Co-precipitation for Removing Traces of Cadmium in Water. Chemistry and Adhesion, 36 (5), 342, 2014 [In Chinese].

5. MERRIKHPOUR H., JALALI M. Comparative and competitive adsorption of cadmium, copper, nickel, and lead ions by Iranian natural zeolite. Clean Technologies and Environmental Policy, 15 (2), 303, 2013.

6. OTREMBSKA P., GEGA J. Separation of nickel(II) and cadmium(II) ions with ion-exchange and membrane processes. Separation Science and Technology, 51 (15-16), 2675, 2016.

7. SARI A., TUZEN M. Cd(II) adsorption from aqueous solution by raw and modified kaolinite. Applied Clay Science, 88-89, 63, 2014.

8. ÁLVAREZ-AYUSO E., GARCÍA-SÁNCHEZ A. Removal of cadmium from aqueous solutions by palygorskite. Journal of Hazardous Materials, 147 (1-2), 594, 2007.

9. KUMAR R., CHAWLA J. Removal of Cadmium Ion from Water/Wastewater by Nano-metal Oxides: A Review. Water Quality Exposure and Health, 5 (4), 215, 2014.

10. KOMKIENE J., BALTRENAITE E. Biochar as adsorbent for removal of heavy metal ions [Cadmium(II), Copper(II), Lead(II), Zinc(II)] from aqueous phase. International Journal of Environmental Science and Technology, 13 (2), 471, 2016.

11. UDDIN M.K. A review on the adsorption of heavy metals by clay minerals, with special focus on the past decade. Chemical Engineering Journal, 308, 438, 2017.

12. WANG Y.Q., FENG Y., JIANG J.L., YAO J.F. Designing of Recyclable Attapulgite for Wastewater Treatments: A Review. ACS Sustainable Chemistry and Engineering, 7 (2), 1855, 2019

13. WANG W.J., CHEN H., WANG A.Q. Adsorption characteristics of $\mathrm{Cd}(\mathrm{II})$ from aqueous solution onto activated palygorskite. Separation and Purification Technology, 55 (2), 157, 2007.

14. WANG W.B., WANG F.F., KANG Y.R., WANG A.Q. Enhanced adsorptive removal of methylene blue from aqueous solution by alkali-activated palygorskite. Water Air and Soil Pollution, 226 (3), 83, 2015.

15. WANG L.L., SHI Y., YAO D.K., PAN H., HOU H.J., CHEN J., CRITTENDEN J.C. Cd complexation with mercapto-functionalized attapulgite (MATP): Adsorption 
and DFT study. Chemical Engineering Journal, 366, 569, 2019.

16. WANG H., WANG X.J., MA J.X., XIA P., ZHAO J.F. Removal of cadmium (II) from aqueous solution: A comparative study of raw attapulgite clay and a reusable waste-struvite/attapulgite obtained from nutrient-rich wastewater. Journal of Hazardous Materials, 329, 66, 2017.

17. ZHA F., HUANG W.Y., WANG J.Y., CHANG Y., DING J., MA J. Kinetic and thermodynamic aspects of arsenate adsorption on aluminum oxide modified palygorskite nanocomposites. Chemical Engineering Journal, 215-216, 579, 2013.

18. PAN M., LIN X.M., XIE J.J., HUANG X.M. Kinetic, equilibrium and thermodynamic studies for phosphate adsorption on aluminum hydroxide modified palygorskite nano-composites. RSC Advances, 7 (8), 4492, 2017.

19. LIN Q.H., GU Y.Q., CHEN D.J. Attapulgite-supported aluminum oxide hydroxide catalyst for synthesis of poly(ethylene terephthalate). Journal of Applied Polymer Science, 129 (5), 2571, 2013.

20. BURNETT M.G., HARDACRE C., MAWHINNEY H.J. The effect of co-precipitation on cadmium(II) adsorption on hydrous aluminium(III) hydroxide in the presence of a range of chelates. Physical Chemistry Chemical Physics, 4 (15), 3828, 2002.

21. TOKORO C., SAKAKIBARA T., SUZUKI S. Mechanism investigation and surface complexation modeling of zinc sorption on aluminum hydroxide in adsorption/ coprecipitation processes. Chemical Engineering Journal, 279, 86, 2015.

22. WANG Y.Z., SHI J., WU R.F., LI X., ZHAO Y.X. Room-temperature $\mathrm{CO}$ oxidation over calcined $\mathrm{Pd}-\mathrm{Cu} /$ palygorskite catalysts, Applied Clay Science, 119, 126, 2016.

23. LIN S.H., ZHOU T.T., YIN S.S. Properties of thermally treated granular montmorillonite-palygorskite adsorbent (GMPA) and use to remove $\mathrm{Pb}^{2+}$ and $\mathrm{Cu}^{2+}$ from aqueous solutions. Clays and Clay Minerals, 65 (3), 184, 2017.

24. CHENG H.F., YANG J., RAY L.F., WU Z.G. Infrared transmission and emission spectroscopic study of selected Chinese palygorskites. Spectrochimica Acta Part A: Molecular and Biomolecular Spectroscopy. 83, 518, 2011.

25. RAY F., SILMARILLY B., JESSICA G. Infrared and infrared emission spectroscopic study of selected magnesium carbonate minerals containing ferric iron Implications for the geosequestration of greenhouse gases. Spectrochimica Acta Part A: Molecular and Biomolecular Spectroscopy. 71, 1610, 2008.

26. HE X., FU L.J., Y H.M. Insight into the nature of Au$\mathrm{Au}_{2} \mathrm{O}_{3}$ functionalized palygorskite. Applied Clay Science, 100, 118, 2014.

27. WANG W.B., TIAN G.Y., ZHANG Z.F., WANG A.Q. A simple hydrothermal approach to modify palygorskite for high-efficient adsorption of Methylene blue and $\mathrm{Cu}(\mathrm{II})$ ions. Chemical Engineering Journal, 265, 228, 2015.

28. DESSALEGNE M., ZEWGE F., DIAZ I. Aluminium hydroxide supported on zeolites for fluoride removal from drinking water. Journal of Chemical Technology and Biotechnology, 92 (3), 595, 2016.

29. XU J.X., WANG W.B., MU B., WANG A.Q. Effects of inorganic sulfates on the microstructure and properties of ion-exchange treated palygorskite clay. Colloids and Surfaces A: Physicochemical and Engineering Aspects, 405, 59, 2012.

30. WANG X.H., WANG A.Q. Removal of $\mathrm{Cd}(\mathrm{II})$ from aqueous solution by a composite hydrogel based on attapulgite. Environmental Technology, 31 (7), 745, 2010.

31. LANGMUIR I. The adsorption of gases on plane surfaces of glass, mica and platinum. Journal of the American Chemical Society, 40 (9), 1361, 1918.

32. FREUNDLICH H.M.F. Uber die adsorption in losungen. Enviromental Science Technology, 20, 385, 1906.

33. KARRI R.R., SAHU J.N., JAYAKUMAR N.S. Optimal isotherm parameters for phenol adsorption from aqueous solutions onto coconut shell based activated carbon: Error analysis of linear and non-linear methods. Journal of the Taiwan Institute of Chemical Engineers, 000, 1, 2017.

34. HUANG X., GAO N.Y., ZHANG Q.L. Thermodynamics and kinetics of cadmium adsorption onto oxidized granular activated carbon. Journal of Environmental Sciences, 19, 1287, 2007.

35. FALAYI T., NTULI F. Removal of heavy metals and neutralization of acid mine drainage with un-activated attapulgite. Journal of Industrial and Engineering Chemistry, 20 (4), 1285, 2014.

36. EL SAID G.F., ABDELREHIM E.S.M., SARA M.E.S.E., KAWY M.H.A. A critical study of interactive fluoride adsorption by raw marine organisms and a synthetic organic 2-amino-3-cyano-4(4-nitrophenyl)6-phenylpyridine as adsorbent tools. Environmental Monitoring and Assessment, 191 (5), 311, 2019.

37. JIANG M.Q., JIN X.Y., LU X.Q., Chen Z.L. Adsorption of $\mathrm{Pb}(\mathrm{II}), \mathrm{Cd}(\mathrm{II}), \mathrm{Ni}(\mathrm{II})$ and $\mathrm{Cu}(\mathrm{II})$ onto natural kaolinite clay. Desalination, 252 (1-3), 33, 2010.

38. MERRIKHPOUR H., JALALI M. Comparative and competitive adsorption of cadmium, copper, nickel, and lead ions by Iranian natural zeolite. Clean Technologies and Environmental Policy, 15, 303, 2013.

39. SARI A., TUZEN M. Cd(II) adsorption from aqueous solution by raw and modified kaolinite. Applied Clay Science, 88, 63, 2014.

40. HUANG R.L., LIN Q.T., ZHONG Q.F., ZHANG X.F., WEN X.Q., LUO H.Y. Removal of $\mathrm{Cd}(\mathrm{II})$ and $\mathrm{Pb}(\mathrm{II})$ from aqueous solution by modified attapulgite clay. Arabian Journal of Chemistry, 13, 4994, 2020. 